\title{
THE USE OF SHINTO FOR THE LEGITIMIZATION OF JAPANESE AGRESSION IN EAST ASIA
}

Araştırma Makalesi / Research Article

\author{
Kadioğlu, A. M. (2021). The Use of Shinto For The \\ Legitimization of Japanese Agression in East Asia. \\ Nevşehir Hacı Bektaş Veli Üniversitesi SBE Dergisi, \\ 11(2), 492-500. \\ Geliş Tarihi: 01.02.2021 \\ Kabul Tarihi: 07.06.2021 \\ E-ISSN: 2149-3871
}

\author{
Dr. Ahmet Murat Kadıoğlu \\ dr.ahmetmkadioglu@gmail.com \\ ORCID No: 0000-0001-9786-1904
}

\begin{abstract}
During the Japanese invasion in China, the spiritual pillar of the modern Japanese imperial system, the Shinto, reflected ideas of military aggression, and shrines were established in a wide range of areas in China, especially militarily and economically important areas. As an extension of the Japanese state, the shrines were dedicated to goddess Amaterasu and Emperor Meiji and other imperial family members. These shrines were not only built for the soldiers who were posted in these areas, but also for the Japanese migrants and later on for the local population. Especially in Taiwan and Manchuria, the local population also seems to have participated in the rituals. The reasons for this phenomenon as well as the reasons for the Japanese government to use Shinto for its political aims in China are discussed in this paper with references to primary sources. Newspaper articles and archival materials from Japan are used for coming to the conclusions, and these materials were read critically to eliminate the nationalist biases on such documents of the period. Since Shinto is often treated as a religion peculiar to Japan, its presence during the war years outside of Japan and its worshippers within the local populations of the occupied areas are rarely examined. Therefore this paper aims to shed light on the Shinto shrines and their aims as well as communities. Since this issue as well as shrines such as Yasakuni and their branches still controversial in China and Japan, the political side and the ideological details are omitted while focusing on the history of the shrines within Mainland China and Taiwan.
\end{abstract}

Keywords: Japan, China, Taiwan, Shinto, Pacific War

\section{JAPON İŞGALINIIN MEŞRULAŞTIRILMASINDA ŞINTONUN KULLANIMI}

\section{ÖZ}

Çin'de Japon işgali sırasında modern Japon İmparatorluk sisteminin ruhani temel direği olan Şinto dini, Japonya'nın askeri saldırganlık fikirlerini yansıtıyordu. Çin'de askeri ve ekonomik açıdan önemli olan geniş alanlara Şinto tapınakları inşa edildi. Bu tapınaklar Japon devletinin bir uzantısı olarak Tanrıça Amaterasu, İmparator Meiji ve diğer önemli imparatorluk ailesi üyelerine adanmışlardı. Bu tapınaklar yalnızca bu bölgelerde görev yapan Japon askerleri için değil, aynı zamanda gelen Japon yerleşimciler ve daha sonra yerel halk için de inşa edilmişlerdi. Özellikle Tayvan ve Mançurya'da yerel halkın da ritüellere katıldığı görülmektedir. Bu fenomenin nedenleri ile Japon hükümetinin Çin'deki siyasi amaçları için Şinto tapınaklarını kullanmasının nedenleri bu makalede birincil kaynaklara dayanılarak irdelenmiştir. Gazete makaleleri ve Japon arşiv belgeleri çıkarımlarda bulunmak için kullanılmış ve bu belgeler dönemin milliyetçi ve taraflı bakış açısı nedeniyle eleştirel bir okumadan geçirilerek analiz edilmiştir. Şinto genellikle Japonya’ya özgü bir din olarak görüldüğü için savaş yıllarında Japonya dışında ve özellikle işgal bölgelerindeki yerel halk arasındaki varlığı nadiren incelenmiştir. Bu nedenle bu çalışma bu bölgelerdeki Şinto tapınakları ile bu tapınakların cemaatlerine 1şık tutmayı amaçlamaktadır. Bu konu ve Yasakuni gibi tapınaklar günümüzde dahi siyasi açıdan Japonya ve Çin'de tartışmalı meseleler oldukları için konuyla ilgili ideolojik ve siyasi tartışmalar göz ardı edilerek yalnızca Çin ve Tayvan'daki bu tapınakların tarihçeleri üzerinde odaklanılmıştır.

Anahtar Kelimeler: Japonya, Çin, Tayvan, Şinto, Pasifik Savaşı 


\section{INTRODUCTION}

Shinto was originally a Japanese folk belief system comprising of different myths and folk lore as well as elements from Buddhism, Daoism, Confucianism and shamanism at different degrees throughout history. During the first stages of its development before the Nara period Shinto was more like a patchwork of animistic and shamanic belief systems of different societies and peoples scattered on the Japanese archipelago (Atik, 2012a: 109). After the Yamato clan united parts of Japan, the myths of the different tribes were compiled. During the Heian period influences from Korea and China also had an impact on the development of Shinto into an organized religion. Actually, from its very early days onwards Shinto was used as a political tool. The imperial family and its ally clans claimed legitimacy and political power through the myths and the creation stories codified in Kojiki and Nihongi. Amaterasu, the son goddess and the mythological grandmother of the first Japanese emperor was placed on the apex of the Japanese pantheon. The other gods and goddesses from whom the other Japanese and sometimes even Korean and Chinese clans claimed descent were placed in accordance with their military and political relationship to the ruling Yamato clan. Later on, during the medieval and early modern periods, Shinto went into a gradual decline along with the fortunes of the imperial and old aristocratic families. During the Edo period, there was an anti-Christian xenophobic tendency among the intellectuals. These movements generally termed as wagaku (和学) were later on influential in the ideology that led to the bakumatsu and the Meiji reformation which claimed to give back the right to govern Japan to the emperor. After the Meiji Restoration, the Japanese government used Shinto as a pretext for its political aims as well as military expansionism until the end of the Second World War.

Establishing Shinto shrines outside of Japan was a new phenomenon that went hand on hand with Japanese expansion overseas. Although the Japanese invaded Korea during the late $16^{\text {th }}$ century under the rule of kanpaku Hideyoshi Toyotomi who united Japan, shrines were not erected in Korea during that brief invasion. Hideyoshi also tried to legitimize his invasion of Korea through Shinto claiming that he saw a dream in which the son goddess giving him orders (Atik, 2012b: 239). The Japanese pirates and samurai who served as mercenaries and the Japanese merchants who established colonies in East Asia and south East Asia during the same time are also not reported to have established Shinto shrines overseas. However, the type of Shinto promoted by the Meiji and later governments was in essence different from the pre-modern Shinto. Beginning with the Kamakura shogunate, the real power gradually fell to the hands of the warrior class, also called as the samurai in modern historiography. Their legitimacy only derived from the imperial decrees that enabled them to rule the different areas of the country "in the name of the emperor" or serve as the proxies of aristocrats and temples who were the original owners of the lands they ruled. Therefore, the Tokugawa shogunate tried to put Shinto under control. Although shinto was never suppressed or banned, and to the opposite, protected by the shogunate, the shogunate promoted Buddhism for legitimizing their rule. In 1665, in a decree issued by the shogunate, the controls on the Shinto shrines and their priests were tightened. Alter on, all the Shinto shrines were ordered to have a Buddhist temple inside, and all the Buddhist temples were ordered to house a shrine. In time, the two religions fused through the exchanges of ideas despite keeping their different identities. Just like the Bön religion of Tibet, Japanese Shinto might have been absorbed by Buddhism had it not been revived by the wagaku (和学) and kokugaku (国学) movements. However, the revived version of Shinto was in many ways different from what it originally was. Shinto which began as a folk belief system and later on folk religion under the influence of Buddhism continued its existence until today in Japan. However, the version of Shinto which is the subject of this paper was deliberately created in the palace during the Heian period and the revived version was again in many ways different from the folk Shinto, but also the medieval one. Its first aim was to prove that the right to govern Japan was solely under the authority of the emperor who descended from the sun goddess Amaterasu. Secondly, by the beginning of the $17^{\text {th }}$ century Japan had already engaged with the European and non-European countries other than China and Korea, the traditional trade and cultural partners of Japan. This reinforced the convictions of the Japanese about their uniqueness as they witnessed the different 
cultures and belief systems. This tendency was not new since Nichiren, a Buddhist monk in Japan who established one of the few native Buddhist sects in Japan that not only thrived in Japan but was also carried by the Japanese to the occupied territories in Assia as will be discussed later pointed out during the $13^{\text {th }}$ century. However, it was Hayashi Razan who not only advocated and in many ways convinced the Tokugawa shogunate for the closed country policy (sakoku/鎖国) but in his works pointed out the necessity to isolate Japan and prevent its unique culture and character from losing its purity by contact with the foreigners (Atik, 2012a: 112). Just like all the other pre-modern societies, Hayashi Razan and others were referring to religion and culture for pointing out their different identities. Just as Christianity, either in its Catholic or Protestant form was a marker along with language but not always necessarily (Spain, France, England and many other countries of Europe had different languages still spoken by their subjects and did not consider the speakers of these languages as alien subjects, but Jews even though speaking the same language and being born in the same city were seen as aliens under law and in the eyes of the sovereigns in many parts of Europe. Japan on the other hand was in a different situation, and yet would use Shinto as an identifier in its nation-building process. Japan mainly belonged to the Confucian and after the $13^{\text {th }}$ century, the NeoConfucian civilization circle, and just like Korea and China, one's ethnicity, language or religion did not matter to be considered civilized and part of the political entity in question. What mattered was one's ability to adopt and retain the socio-political cultural requirements of Confucianism and NeoConfuciansim. The Europeans, Manchus, Mongols or South East Asians that the Japanese encountered beginning from the $16^{\text {th }}$ century onwards could thus be used as outsiders to use as the other while the Chinese and the Koreans could settle within the Japanese society from the very early times onwards. However, the Manchus and their dynasty in China created a problem for the NeoConfucian ideology just as it did during the Mongol Yuan dynasty. While the Koreans, as a result of Manchu occupation, accepted the Manchu's receiving the mandate of heaven, the Japanese did not accept it, and even discussed for a while, invading China and saving it from barbarian invasion. But due to different reasons, both the Koreans and the Japanese decided on a closed country policy distancing themselves from the westerners as well as the Chinese. The Japanese also feared Christianity, which was at the core of the sakoku arguments of Hayashi Razan, but the developments in China no doubt influenced their decisions. After a long round of discussions, the shogunate decided not to deal with either the Christians or the Manchu both of which were seen as external threats. However, in order to suppress Christianity in Japan, the authorities utilized both the Buddhist clergy and the Shinto shrines. Every new born Japanese was compulsorily registered in a Shinto shrine where his/her family members were also registered and they were obliged to attend Buddhist temples and their rites as well. While the Shinto clergy who were by this time in a way subsumed by the Buddhist clergy were not given a role other than registering the newborn and submitting the records to the authorities if needed, the Buddhist clergy were held responsible for observing and reporting the families under their register.

\section{METHODS AND DATA}

The worship of Shinto outside of Japan, especially in China, Taiwan and Korea is a controversial issue even today and it was quite difficult to document first hand testimonies from those who witnessed the events. Therefore, mainly the documentary evidence at hand from the Japanese sources of the era as well as the secondary studies on the issue with extensive use of first hand materials have been chosen. As mentioned above, since the participants of Shinto rituals hid themselves after the Japanese occupation ended, it was also close to impossible to find documents in China and Korea since these were mostly destroyed. As a result the Japanese documents at hand were used for supporting the main arguments after some critical reading of especially the first hand materials since they were especially prone to being biased as a result of the ongoing nationalist atmosphere and the war. Archival documents and the first hand materials were accessed digitally from the digital archives of Japan. Secondary sources were borrowed from libraries in Canadian and Turkish University libraries. 


\section{DISCUSSION}

As mentioned in the introduction, with decrees concerning the Shinto clergy, the religious activities of the monks, more importantly their political roles were limited. However, this would change with the Meiji restoration. The supporters of Emperor Meiji derived the legitimacy of their rebellion against the shogunate from the Shinto schools of thought and not surprisingly, these cliques made Shinto the state religion after they came to power. Emperor Meiji was proclaimed a living god and deified after his death. Perhaps the most prominently political use of Shinto for propaganda and legitimization of Japanese aggression in East Asia was the Yasakuni Jinja which still remains to be a controversial shrine among the Japanese as well as the neighboring countries. On $9^{\text {th }}$ of December 1867, with the imperial decree the Meiji government was announced. One of the first acts of the government was to proclaim Shinto as the state religion. On March 1868, Daijôkan (太政官) announced that the imperial system as had been decreed by the first emperor Jimmu would be restored(Kodama Kota \& Okubo, 1960: 174). The same year in October Emperor Meiji announced in the sacrificial rituals of Hikawa Shrine in Saitama that "since Emperor Shujin (崇神) observing the sacrifices by the imperial palace has been the foundation of government and religion" (Kenichi Sakamoto, 1981: 208-209). In July 1869, Meiji government made administrative reforms and the Jingikan (神祇官) under the Daijokan was upgraded to the same status as Daijokan. At the same time, the sacrificial rituals in the shrines were rectified and reformed on a national scale. On February 2 1870, the Taikyo Senpu was announced by the emperor which stipulated that Shinto would proselytize and new shrines and offices would be established for this purpose (Kenichi Sakamoto, 1981: 211). These offices and shrines were to teach people how to revere and worship the gods and the emperor "correctly". This became one of the most efficient ways of promoting nationalism and using Shinto, which normally was more of an animistic nature as a nationalist ideology. In March 1872, the government began a movement to educate the public about Shinto. In order to reinforce the influence of the office on the general public, Buddhist teachings were also included and the office undertook to teach a "national" Buddhist version of the religion. In April 1875, the Bureau of Shinto Affairs was established and given responsibility over all the Shinto shrines in the country and teaching of Shinto was put under this new bureaus responsibility. In 1880, the members of the bureau were divided into Ise and Izumi factions and the famous controversy of the gods began. The Ise faction claimed that only three gods (Amenominakanushi, Takamimusubi and Kamimusubi) and the major gods were to be revered whereas the Izumi faction also revered the other gods. This controversy continued until Emperor Meiji intervened in March 1881 and decreed that the god of each shrine was to be worshiped along with the ruling emperor, the past emperors and the royal gods. In $190027^{\text {th }}$ of May, the Meiji government further interfered in the religious affairs of the country by setting up a Shinto Bureau within the Ministry of Internal Affairs while leaving the management of the other religious institutions in the Bureau of Religious Affairs (Koremaru Sakamoto, 1994: 305-311). This move clearly set Shinto apart from the other religions with the implication that Shinto was a state religion and at the same time a state affair. After a series of such reforms, Shinto became in essence the state religion of Japan while this new type of Shinto came to be called as state Shinto by the later historians, the folk Shinto continued to exist to some extent. After Japan entered the WWI, it declared war on Germany and took over the German colonies in China and the Pacific Ocean. Along with Taiwan, these new colonies became the earliest Chinese speaking areas coming under Japanese control. While in Japan Shinto was used for raising the military spirit by praying fro the military and the empire as well as the emperor and building state Shinto shrines such as Yasakuni Shrine which was dedicated to the souls of the Japanese soldiers who died abroad, the Japanese government also began to build Shinto shrines in its newly invaded territories in Korea and China as well.

The first introduction of Shinto into China began in Taiwan after Japan annexed the island following the Sino-Japanese war. In June 1895, Japan invaded Taiwan and the Penghu Islands and appointed Hiyama Yuki as governor. There were two Shinto priests accompanying the army named Yamaguchi Satoshi and Kai Kazuhiko (Japan Prime Minister's Office, 1900). After a special 
administrative office was established for Taiwan, Shinto Shrines were also erected in memory of the marine soldiers (Ogasawara, 1953: 54). The Great Taiwan Jinja was established in October 1900 in Taipei by Yamaguchi Satoshi as the first Shinto Shrine in China. Until their surrender in 1945, the Japanese government established throughout the island in important cities such as Tainan, Gaoxiong, Taizhong, Xinzhu, Hualian etc. as branches of the Great Taiwan Shrine and the other shrines dedicated to Shinto gods or the emperor and the state, but most importantly to Prince Kitashirakawa Yoshihisa. Prince Kitashirakawa was deified after he died of Malaria near Tainan while commanding the elite $1^{\text {st }}$ division of the army. He was the first imperial family member of Japan to have died outside of Japan (Asami, 2008: 121) and the first to die in battle since the Songoku Jidai (Era of Warring States). He was actually a Buddhist priest during the Edo period but after the Meiji Restoration, he became the head of his family following his brother's death (Yuoka, 1998: 81). Following the Sino-Japanese War and occupation of Taiwan and other areas, Russia and Japan waged war on each other for supremacy over Korea and Manchuria. In 1905 Russia was defeated and the parties signed the Portsmouth Treaty. Following the treaty, the Japanese established the Andong Shrine in Manchuria on a strategic point for entry into Korea near the Yalu river. This was actually preceded by the first Japanese military colony in Andong which was established in May 1904 during the war. Later on, according to the records of Manchuria Shrines Bureau, there were 42 shrines in Manchuria as of 1930 (Ogasawara, 1953:255-256). The Great Taiwan Shrine and the Andong Shrine were probably established for the Japanese military by the priests accompanying the Japanese army as in the example of Yamaguchi Satoshi. However, the shrines in rural and urban areas must have been aimed at promoting Shinto in these areas within the public. After the second Sino-Japanese War, Japan swiftly began to take over territories in China, especially the North East. It was claimed by some of the proponents of State Shinto such as Horie in Kôkoku Jihô (Imperial Times Newspaper) that one of the most urgent issues in Manchuria and North Eastern China was to establish Shinto shrines and promote Shinto there (Hideo, 1932: 31). In fact, there were different types of Shinto shrines established in China. Without exception, the first type was established by the military serving the needs of the military. Secondly, the Manchurian government which was created by the Japanese occupation forces as a puppet state to legitimize the Japanese occupation there. These shrines were aimed at the local population in Manchuria rather than the Japanese soldiers. The third kind of shrines were established in urban and rural areas for the Japanese migrants as well as the local residents as mentioned above.

At this point, it might seem ironic that a religion modified for the nationalist and aggressive ambitions of a country should be used for legitimizing its occupation of a foreign land in the eyes of the residents of the occupied area. While the use of Shinto for legitimizing the occupation of Korea was based on Hachiman myths, there was no precedent for China. But the state Shinto served the purpose of deifying the soldiers who died in battle, thus mitigating the reactions within the Japanese society against war. It was also used for giving morale to the soldiers on the battlefield as was seen in the example of kamikaze attacks by the pilots who were indoctrinated to believe that they would become gods after death. While these actions are understandable for the Japanese public, the Korean and Chinese participation in state Shinto rituals and shrines needs explaining. For China, although there was a sense of Chineseness, it was different from Japan which had evolved into a modern nation and was previously relatively an ethnically homogenous country in pre-modern times. China on the other hand, had already been under Manchu rule since $17^{\text {th }}$ century, and ethnicity or nationality in a modern sense was only limited to a narrow circle of intellectuals. In this respect, the Japanese were from a traditional point of view, no different than the Mongols or the Manchus. In fact, from a Confucian point of view, the Japanese Emperors, having embraced both traditional and later on the $\mathrm{Zhu} \mathrm{Xi}$ version of Neo-Confucianism were a better choice than the Manchus or Mongols who were considered to be barbarians (Atik, 2021: 349). Other than Confucianism, Buddhism was also a uniting element for the Japanese and their neighbors, but the use of Shinto was controversial. However, a holistic approach to Shinto and Daoism will reveal some apparent resemblances. Although from a meticulous theological and philosophical points of view, the two religions were quiet different despite the ostensible similarities, for an ordinary Chinese or a Manchu, Shinto offered familiar ideas such as ancestral worship, sacrificial rituals, local gods and a syncretism with 
Buddhism. This in a way explains the participation of some local residents in the Shinto rituals of shrines as mentioned by a shrine community of the Tianli village in Manchuria (Sakurai, 1998: 223). Although some of the incentives were most probably political and economic favors to be gained from participating in the rituals alongside the new ruling class of Japanese soldiers and officials for the bourgeoisie and bureaucracy, for the rural population as in the Tianli village where Chinese villagers and Japanese migrants of peasant origin cohabited, such an act was not necessary. In many ways Shinto was perhaps just another religion that entered China like Buddhism, Christianity and Islam, and with its syncretic nature had the ability to be more flexible. The Chinese society still exhibited a traditional structure to a great extent which was one of the reasons the nationalists failed where the Communist party succeeded having perceived the "feudal" structure. Therefore, just like Christianity, Shinto might have been accepted by the local population as a new religion coming from abroad. Since in Korea and China, collaboration with the Japanese occupation forces is still a controversial issue, studies on this topic are very limited and are hard to conduct since participants would understandably be unwilling to admit such participation, it is hard to estimate exact numbers and the perception of Shinto by the local population. Another question is why did Japan choose Shinto as a legitimizing and uniting tool in China and Korea instead of Buddhism, which they already shared. The Mongols and the Manchus promoted Buddhism as a state religion despite having their own religions such as Tengrism. In addition to using state Shinto for motivating the Japanese population in times of war, the Japanese government which was dominated by the nationalists saw state Shinto as a $n$ important ideological tool. The Japanese Consul in Beijing stated in 1940 that the Beijing Shinto Shrine established in Gongyuan would not only bring spiritual joy to the Japanese residents in Beijing, but would also help the Chinese residents to recognize the greatness of Japan and to help Chinese people to regain their glory and be united with the Japanese people (Murakami, 1986: 214). While Buddhism preached equality of humans and peace, for the nationalist government Shinto served their purposes better by claiming descent from gods for the imperial family and a set of gods creating Japan as a superior country for a superior race. Secondly, especially in Taiwan and Manchuria which had relatively smaller populations, the Japanese government pursued an assimilation policy followed by Korea. Shinto in this respect offered a better alternative to Buddhism. Traditionally in Japan, families were expected to, in fact, beginning from 1640 until the lift of ban on Christianity following the Meiji Restoration, they were responsible for registering the new born babies to shrines and enter their names in the family registers of the shrines. While the Chinese also had the tradition of keeping family records, families mostly did this. However, registering families in Shinto shrines and associating them with certain gods was expected to create a mutual identity and sense of belonging with Japan. Thirdly, the local populations in these areas would be accepting the Japanese Emperor and the imperial family as their rightful sovereigns by worshipping them in the shrine thus creating a sense of a simple dynastic change from the Manchu Qing to the Japanese rather than a foreign invasion. As Atik states, the roots of associating Shinto with state ideology went back to the Edo period was closely related to Japanese political modernization (Atik, 2012a: 103). Therefore, despite originally not being a religion with universal claims such as Buddhism and Christianity, Shinto offered an alternative to the newly emerging colonial power in its modified form.

\section{CONCLUSIONS}

Japan's occupation of China although relatively brief compared to the other colonial powers left enduring marks on the public memory and Shinto Shrines such as Yasakuni still play a controversial role in the politics of Japan both within and without in its relations with its neighbors. Shinto which seemed to have been absorbed and assimilated by Buddhism actually played a major role in the aftermath of the Meiji Restoration as explained above, and its role in China following the Japanese occupation is rarely dealt with due to its political implications today, and when studied this topic is rarely dealt with by excluding the current politics and nationalism due to the sufferings of the past century by the people in the occupied territories. However, the use of Shinto as an ideological tool by Japan during this period needs to be studied more objectively in terms of its history of religion side. This period was the only one in world history for an originally animistic belief system to turn into a state ideology and an organized religion in a modern sense and spread over a large area. While 
the Mongols and Turks also brought their shamanistic Tengri belief systems with them to the lands that they conquered in medieval times and the Mongols made it their state ideology in a similar way to the Japanese state Shinto centuries before them, they did not try to or permit it to spread among the local populations where they went. Although this paper deals with the historical side of spread of Shinto in China through the state shrines, theological side of State Shinto also needs to be examined in further detail especially concerning its view of "foreign" converts.

\section{BIBLIOGRAPHY}

Asami, M. (2008). 皇族誕生 [Kōzoku Tanjō]. Kadokawa Shoten.

Atik, K. (2012a). Japonya, Kapalı Ülke, İdeoloji ve Din. Doğu-Batı, 60, 101-118.

Atik, K. (2012b). Kore Aydınlanması: Joseon Dönemi. Doğu Batı, 61, 217-232.

Atik, K. (2021). A Comparison of Komnenos Era Byzantine and Song Era Chinese Diplomacy with Nomadic Neighbors. Atatürk Üniversitesi Türkiyat Araștırmalarl Enstitüsü Dergisi, 70(1), 343-358. http://www.turkiyatjournal.com/DergiTamDetay.aspx?ID=4433

Hideo, H. (1932, January 2). 神道の满蒙進出［Shinto no Manmô Shinshutsu]. 皇国時報 [Kôkoku Jihô].

Japan Prime Minister's Office. (1900). 台湾神社宮司山口透叙位ノ件 [Taiwanjinja Güji Yamaguchi Tōru Joi no Kudan] (Main building-2A-016-00). National Archives of Japan Digital Archives; NATIONAL ARCHIVES OF JAPAN. https://www.digital.archives.go.jp/das/meta/M0000000000000331187

Kodama Kota, \& Okubo, T. (1960). 史料による日本の歩み: 近代編 [Shiryō ni yoru Nihon no ayumi: Kindai-hen]. Yoshikawa Kobunkan.

Murakami, S. (1986). 天皇制国家と宗教［Tennōsei Kokka to Shūkyō]. Nihon Heironsha.

Ogasawara, S. (1953). 海外神社史 [Kaigai Jinja Shi] (Vol. 1). Kaigai Jinjashi Hensankai.

Sakamoto, Kenichi. (1981). 明治神道史 [Meiji Shinto Shi] (2nd ed.). Tokyo Daigaku Shuppansha.

Sakamoto, Koremaru. (1994). 国家神道形成過程の研究 [Kokkashindō keisei katei no kenkyū]. Iwanami Shoten.

Sakurai, K. (1998). 渶州の神社興亡史［Manshu no Jinja Kōbō-shi]. Fuyōshobō Shuppan.

Yuoka, Y. (1998). 皇族 [Kōzoku]. Yomiurishinbunsha. 


\section{GENIŞLETILMIŞ ÖZET}

\section{Amaç}

Bu çalışmanın amacı Japonya'nın Pasifik Savaşı adı verilen aslında İkinci Dünya Savaşından önce başlamış işgal hareketleri sırasında Çin'in farklı bölgelerinde kurmuş olduğu Şinto tapınaklarını ve bu tapınaklarda yürütülen ayinlere katılımı belgeler 1şı̆̆ında inceleyerek Japonya'nın Çin’de ve Asya'nın diğer bölgelerindeki işgallerini meşrulaştırmada bu tapınakların rolünü incelemektir. Bu konu Türkiye'de hiç dikkat çekmediği gibi dünya literatüründe de dikkatlerden kaçmıştır ve bu nedenle hem Türk okurların ve akademisyenlerin hem de genel olarak akademinin yararlanması açısından alana katkıda bulunması ümit edilmektedir. Japon işgali genellikle askeri operasyonlar ve sivillere yapılan zulüm üzerinden işlenen bir temadır. Ancak bu işgalin kültürel ve düşünsel hegemonya kurma yönü nadiren dikkat çekmektedir ve aslında Japon işgal planlarının önemli bir parçasıdır. Bu nedenle bu alanda daha fazla çalışmalar yapılması yararlı olacaktır. Japonya'nın pasifik savaşı sırasındaki faaliyetleri ve genel olarak Japon düşünce tarihi de ülkemizde çok az ilgi görmüş ve çalışılmış bir alan olması nedeniyle bu alanda daha fazla çalışmaya ihtiyaç duyulmaktadır. $\mathrm{Bu}$ nedenle bu çalışma bu alanda özellikle Japonya'ya özgü olması nedeniyle Japonya dışında inananları bulunmadığı ve yayılmadığı varsayılan Şinto dininin işgal sırasında yalnız Çin’deki Japon askerleri arasında değil, Çinli ve diğer uluslardan kişiler arasında da yayılma gösterdiğini belgeler ve ikincil kaynaklar ışığında göstererek bu alanda katkı sağlanması umulmaktadır.

\section{Yöntem}

$\mathrm{Bu}$ çalışmada başvurulan temel yöntem arşiv belgeleri ve ikincil kaynak ve araştırmaların analizi olmuştur. Bu konu günümüzde dahi Japonya'da ve diğer Doğu Asya ülkelerinde bireyler açısından sosyal dışlanma ve bazen de hukuki sonuçları olabilecek suçlamalara neden olmaktadır. Özellikle Kore ve Çin’de savaş dönemindeki “işbirlikçiler” konusu günümüzde dahi yalnız popüler kültürde değil siyasi ve sosyal alanda da hassas bir konu olmayı sürdürmektedir. Bu nedenle bu çalışmanın konusunu oluşturan ve Japon olmayan bireyler hakkında doğrudan isim vererek örnekler vermek kendileri yaşamakta olanları tehlikeye atabileceği gibi hayatta olmayan kişilerin de aileleri için toplumsal dışlanma ve yargılanmayla sonuçlanabilir. Bu nedenle çalışma kapsamında kullanılan arşiv belgeleri ve ikincil kaynaklarda mümkün olduğunca bireysel isimlere yer verilmeyip sayısal verilere ve tarihlere yer verilmiştir. Ayrıca kullanılan belge ve kaynaklardaki milliyetçi ve taraflı dil de göz önüne alınarak kaynaklar eleştirel bir okumadan geçirilmiş ve bu şekilde analiz edilmiştir. Nitekim kaynaklar devlet arşivi olması ve bu konuda yukarıda da belirtildiği gibi bireylerin gönüllü olarak deneyimlerini paylaşmaması nedeniyle kaynakların dikkatli bir şekilde ele alınması gerekmektedir.

\section{Bulgular}

Japon işgali sırasında Çin'de de tıpkı Kore'de ve diğer Asya ülkelerinde olduğu gibi çok sayıda asker ve sivil yaşamını yitirmiştir. Aslında İkinci Dünya savaşı ile birlikte ve onun bir kolu olarak ele alınsa da bu bölgedeki savaş İkinci Dünya savaşından çok önce başlamış ve aralıklarla devam ederek Japonya'nın teslim olmasına kadar sürmüştür. Ancak bu süreç sırasında Japonya yalnızca askeri gücü ile değil yumuşak gücü ile de sahada etkin bir şekilde rol almış, Kore ve Mançurya'da okullar açarak birkaç nesli Japonca eğitimden geçirmiş, ayrıca düşünce alanında da tüm bölgede savaştan çok öncesinde egemen güç haline gelmiştir. Savaştan önce ve savaş sırasında çok sayıda Asya'lı genç Japonya'da eğitim almıştır. Buna ek olarak Japonlar işgal ettikleri önemli bölgelerde Tayvan ve Kore'den başlayarak zamanla Mançurya ve diğer bölgelerde de Şinto tapınakları kumuşlardır. Bu tapınaklar ilk başlarda bu bölgelerde görev yapan askerler ve aileleri ile bu bölgelere yerleşimci olarak gelen Japon aileler için kurulmuşlardı. Ancak zaman içerisinde bu tapınaklarda ibadete yerli nüfusun da geldiği görülmektedir. Bunun ise çeşitli nedenleri olduğu görülmektedir. İşgal hükümeti içerisinde görev alarak yükselmeden, Şinto’yu yerel dinlerle yakın bulmaya kadar uzanan geniş bir yelpazede sıralanabilecek nedenlerle işgal sırasında kurulan Şinto tapınaklarında ibadet ve ritüellere katılan Çinli, Mançu, Koreliler olmuş, ancak savaştan sonra bu durumu gizleme gereği duymuşlardır. Bu gizlilik ve siyasi sonuçlar nedeniyle bu konu uzun süre çalışılmamıştır. 


\section{Sonuç ve Tartışma}

Japonya'ya özgü yerel bir inanç sistemi olan ve aslında erken modern dönemde ve sonrasında modern dönemde devlet müdahalesi ile daha sistematik ve örgütlü bir dine dönüştürülene kadar Şinto birbirinden yerel farkl11ıklar gösteren animistik ya da yerel tanrılara olan inançlar bütününe verilen isim olarak kalmıştır. Budizmin gelmesinden sonra Budizm tarafindan absorbe edilmesine rağmen, Asya'da Kore, Tibet gibi ülkelerin aksine varlığını sürdürmeyi başararak daha sonra ideolojik nedenlerle devlet himayesinde güçlenerek geri dönmüsşür. Daha önce Japonya dışında yayılma şansı bulamamış olan Şinto inancı Japonya'nın önce Kore ve Tayvan'ı daha sonra ise Çin'in çeşitli bölgelerini işgal etmesi ile birlikte Asya'da ilk kez Japonya dışında da yayılma firsatı bulmuştur. Japon askeri gücünün uzantısı olarak işgal edilen bölgelere giden Japon yumuşak gücünün bir uzantısı olan Şinto ilk başlarda bu bölgelerde yaşayan ve çalışan Japonlar için bu bölgede kurulan tapınaklarda yerel nüfusa da etki etmiş ve çok çeşitli nedenlerle savaş sonuna kadar taraftar bulmayı başarmıştır. Bu konu çok az akademisyen tarafından çalışma konusu edilmiş ve dikkat çekmemiştir. Bunda savaş sonrasında "işbirlikçi” olarak suçlanma korkusu ve Japonya'ya dair her şeyden nefret etme ve suçlama tepkisinin etkisi son derece büyüktür. Günümüzde dahi Tayvan'da işgal döneminden kalan Şinto tapınaklarının yalnızca varlıklarını sürdürmekle kalmayıp aynı zamanda yeniden ibadete açılmaları ise bu bölgelerdeki yayılışın yalnızca işgal hükümetinin gözüne girmek ve işgalcilerle işbirliği yapmak olmadığını bazı kişilerin zorlama olmadan buralarda ibadet ettiğini göstermektedir. 